\title{
Polen. Aske og diamanter
}

\author{
Ingrid Brekke
}

Oslo: Humanist Forlag 2019

325 sidor. ISBN 9788282821780

Recenserad av Barbara Törnquist-Plewa [professor i Öst- och Centraleuropastudier, Lunds universitet, Barbara.Tornquist-Plewa@slav.lu.se]

Sedan kommunismens fall och EU:s utvidgning i öst har kontakterna mellan de nordiska länderna och Polen väsentligt intensifierats, inte minst på grund av en betydande arbetskraftsinvandring från Polen. Enbart i Norge arbetar för närvarande över hundratusen polska medborgare. Mötena mellan polackerna och skandinaverna är således många men kunskapen om Polen är fortfarande mycket begränsad. De som vill stilla sin nyfikenhet på detta land genom att läsa en bok på något av de nordiska språken har hittills inte haft särskilt mycket att välja på. Länge utgjorde journalisten Kjell Albin Abrahamsons svenska böcker om Polen de mest lättlästa och för allmänheten mest tillgängliga publikationerna. Abrahamson fick emellertid under de senaste tio åren en stark och historielärd konkurrent i en annan svensk journalist Peter Johnsson. Denne har bland annat utgivit Polen i historien (2011) och Polen! Quo vadis?: om Polen $i$ dagens Europa (2017). Även danska och norska journalister har på senare år börjat visa större intresse för Polen. År 2019 fick landet en beskärd plats i den danska boken Kampen om Centraleuropa av Vibe Termensen och samma år begåvades den norska bokmarkaden med Polen:Aske og diamenter av Ingrid Brekke.

Den sistnämnda boken fokuserar helt och hållet på Polen och har ambitionen att fylla ett vakuum på den norska marknaden genom att leverera en lättläst, informativ text, som kan hjälpa läsarna att bättre förstå det nutida Polen. Författaren har enligt mig lyckats med denna föresats. Boken är skickligt skriven även om dess konstruktion avslöjar att Brekke förmodligen använt sig av sina tidigare publicerade texter. Den utgör nämligen ett collage av reportage om specifika platser i Polen (t.ex. Warszawa, Oświęcim/Auschwitz, Stalowa Wola) och intervjuer med kända och okända polacker. Hon har fogat samman detta material på ett finurligt sätt och först och främst kompletterat det med historisk information samt egna och andras reflektioner över Polens förflutna och samtid.

Brekke belastar inte boken med någon kronologisk återgivning av historien. Den sammanfattas på några få sidor $i$ inledningen. Därefter tar författaren avstamp i dagens politiska skeenden och debatter och fokuserar på dem medan hon samtidigt 
försöker förstå och förklara dem ur historiskt perspektiv. På det sättet åskådliggör hon den vikt och sprängkraft som historien har i dagens polska samhälle. Kapitlet om massmordet i Katyn och flygkatastrofen i Smolensk 2010 illustrerar detta tillvägagångssätt bra. Ett annat fint exempel är kapitel 2 i vilket Brekke beskriver sitt besök i en avlägsen by, Kruszyniany, där man kan finna en moské tillhörande en tatarisk, muslimsk minoritet med rötterna i medeltiden. Reportagen om denna by används för att berätta om tiden då Polen var en mångkulturell och mångetnisk stat. Historia och nutid möts i stort sett i bokens alla kapitel. Bokens stora behållning är att författaren försöker tränga bortom ytan och läsaren kan uppleva att hon verkligen vill förstå Polen och polackerna. Det märks kanske tydligast i kapitel 4 då hon insiktsfullt och med stöd i forskningen diskuterar antisemitism i Polen förr och nu, samtidigt som hon tar avstånd från stereotyper om polsk antisemitism. På ett kärnfullt och objektivt sätt återger författaren de debatter om Förintelsen och polsk-judiska relationer som ägt rum i Polen sedan kommunismens fall.

Brekkes bok har många förtjänster, men undgår inte en del förenklingar, feltolkningar eller små fel. På sidan 56 sammanfattar hon till exempel Stalins politik gentemot nationella minoriteter på ett sätt som ingen specialist $\mathrm{i}$ ämnet skulle acceptera. Vidare förklarar hon på sidan 85 att anledningen till avsaknaden av en polsk Quisling i det ockuperade Polen var att tyskarna aldrig försökte alliera sig med polackerna eftersom de var slaver och därmed kategoriserades som underlägsen ras. Denna argumentation håller inte om man betänker att Nazityskland samarbetade till exempel med Slovakiens fascistiska regering eller med ledningen för Ustaša i Kroatien. Många historiker har dessutom visat klart att tyskarna före 1939 försökte att övertala den polska statsledningen att alliera sig med dem i ett planerat krigståg mot Sovjetunionen. På sidan 114 accepterar Brekke okritiskt en tolkning av en annan Polenobservatör som ansåg att den polska regeringen ledd av det nationalkonservativa partiet PiS var en solklar vinnare i striden kring den så kallade Förintelselagen. Denna handlade om regeringens försök att 2019 göra en lagändring som gick ut på att kriminalisera anklagelser mot polska nationen och staten för medverkan i Förintelsen eller andra folkmord. Under internationell press, särskilt från EU, USA och Israel, fick regeringen nöja sig med en symbolisk markering och avstå från kriminaliseringen. Det innebar ändå en stor prestigeförlust för regeringen både i utlandet och på hemmaplan. De liberala och vänstern var från början starkt mot förslaget, och högern kunde hävda att regeringens kompromiss visade att den gick i USAs och Israels ledband. Det är således svårt att se detta som en solklar seger även om PiS-regeringen helst ville framställa det på det viset. Det finns några andra ställen där små felaktigheter dyker upp. Ett sådant som går lätt att korrigera $i$ en eventuell nästa upplaga finns på sidan 160 där Brekke skriver: „En tidligere gruvearbeider i Radom fortalte meg en gang ...» Radom har aldrig haft några gruvor så denne arbetare måste ha jobbat på en helt annan ort. Sammanlagt är dock dessa skavanker få och förlåtliga eftersom Brekke kompenserar det väl med sitt engagerande sätt att skriva. I bokens slutord (Tackordet) skriver Ingrid Brekke att hon hoppas på 


\section{8 | BARBARA TÖRNQUIST-PLEWA}

att boken visar att hennes hjärta brinner för Polen. Det gör den, och jag tror också att den har potential att tända läsarnas intresse för Polen.

Brekkes bok representerar en speciell genre av populärvetenskapliga böcker skrivna av journalister. Enligt min mening kan hon inte mäta sig med den tidigare nämnde Peter Johnsson ifråga om rejäla historiska kunskaper, noggrannhet och djup i analyserna (för att inte tala om språkkunskaper). Hennes bok spelar däremot i samma klass som Kjell Albin Abrahamsons av allmänheten uppskattade publikationer om Polen. Brekke har nog inte samma sinne för det humoristiska som den för tidigt avlidne Abrahamson hade, men hon uppvisar samma förmåga på inlevelse i Polens öden och fascination för landet. När jag betraktar titeln på Brekkes bok undrar jag dessutom om hon bestämde sig för den för att markera att hon har Abrahamson som sin förebild. En av Abrahamsons mer kända böcker om Polen, utkommen 2013, heter nämligen Polen: diamant $i$ aska med anspelning till en polsk kultfilm från 1958 Aska och diamanter. Syftar titeln på Brekkes bok på båda? 